\title{
Response of Domestic Prices to Exchange Rate Movements in Argentina
}

\author{
Yu Hsing \\ Department of Management \& Business Administration \\ College of Business, Southeastern Louisiana University \\ SLU Box 10813, Hammond, LA 70402, USA \\ E-mail: yhsing@selu.edu
}

Received: April 8, 2021 Accepted: April 29, 2021 Published: May 6, 2021

doi:10.5296/ber.v11i2.18604 URL: https://doi.org/10.5296/ber.v11i2.18604

\begin{abstract}
Based on an extended IS-LM-AS model, this study finds that if the Argentine peso depreciates $1 \%$ versus the U.S. dollar, the consumer price in Argentina would increase by $0.2518 \%$. In addition, more structural fiscal deficit as a percent of potential GDP, more M2 supply, a higher U.S. price level, and a higher expected price level would raise Argentina's consumer price level. Therefore, partial exchange rate pass-through is confirmed for Argentina.
\end{abstract}

Keywords: Exchange rate pass-through, Currency depreciation, Consumer prices, Money supply, Crude oil prices

\section{Introduction}

Studying the impact of currency depreciation on the domestic price in Argentina is probably more significant than many other countries partly because the Argentine peso experienced drastic depreciation of $663.97 \%$ from 9.2332 pesos per U.S. dollar in 2014 to 70.5392 pesos per U.S. dollar in 2020. The depreciation was mainly caused by high inflation, potential default of its sovereign debt, change from a pegged to a floating exchange rate regime, capital outflows partly triggered by higher interest rates in the U.S., and government action to devaluate the over-valued peso to stimulate the economy (BBC, 2018; Castillo-Ponce and Lai, 2020). With such substantial depreciation, it is interesting to determine whether the domestic price level would be affected considerably as expected rising import costs tend to pass to consumer prices. Currency depreciation tends to raise import prices, which cause aggregate supply to shift to the left and stimulate net exports, which cause aggregate demand to shift to the right. Anticipated currency depreciation is likely to cause outflows of international capital, 
which tends to cause consumption and investment spending to decline and shift aggregate demand to the left.

This paper has several different aspects. This paper applies an extended IS-LM-AS model to describe the extent and magnitude of the impact of currency depreciation on the domestic price level. Besides the exchange rate, several other relevant variables are incorporated in the model. External shocks including crude oil prices are considered.

\section{Literature Survey}

Based on a sample of seventy-one countries during the period of 1980-1998, Goldfajn and Werlang (2000) indicate that ERPT is estimated to be $0.25,0.34$, and 0.39 for the advanced, developing and emerging countries in the short run and $0.61,0.51$ and 0.91 for the advanced, developing and emerging countries in the long run. These results suggest that the extent of ERPT for emerging countries is greater than those for advanced and developing countries. GDP deviation, initial inflation, openness, initial overvaluation of the exchange rate are major determinants of the degree of ERPT.

Based on a sample of seventy-one countries during the period of 1979-2000, Choudhri and Hakura (2006) find that there is strong support for a positive relation between ERPT and the inflation rate by country and over time. Besides, the inflation rate is a dominant factor than other macroeconomic factors. For Argentina, during high inflation periods, ERPT is estimated to be in the range of 0.62- 0.67 in the short run and $0.79-1.09$ in the long run. However, during the moderate inflation period, ERPT ranges from 0.01 in the short run to -0.09 in the long run.

Ca'Zorzi, Hahn and Sánchez (2007) reveal that ERPT to consumer and import prices are higher in emerging economies than developed countries, that those emerging economies with relatively low inflation rates tend to have similar degree of ERPT to developed countries, and that there is a weak support for the positive relationship between ERPT and import openness. For Argentina, exchange rate pass-through to the consumer price index is estimated to be 0.39 in the long run.

Mihaljek and Klau (2008) show that ERPT is confirmed for Columbia and Peru and has declined in Columbia, Peru and Venezuela, that exchange rate pass-through for the consumer price is less than import prices, and that complete ERPT would reach after 2 years.

Assessing ERPT for twelve Latin American countries and fifteen African countries during 1980 - 2005, Akofio-Sowah (2009) find that ERPT for Latin American countries is incomplete and estimated to be 0.189 in the random effect and 0.203 in the fixed effect. The inflation regime is an important variable. If inflation is lower, ERPT will be smaller.

Coulibaly and Kempf (2010) show that inflation targeting reduces exchange rate shocks to the CPI from $19.18 \% \mathrm{v}$ to $13.62 \%$ in the long run. For non-inflation targeting countries, before 1999, exchange rate shocks explain $1.09 \%$ of the variance in the CPI in the long run, and after 1999, exchange rate shocks explained $2.94 \%$ of the variance in the CPI in the long run. Exchange rate shocks to price changes is less important in non-inflation targeting 
countries than in emerging inflation targeting countries

Cheikh and Louhichi (2016) find two threshold points, split the sample into three inflation regimes, and found that ERPT is strongly regime dependent and that a higher inflation rate led to a higher degree of ERPT.

In reviewing ERPT in South American countries who are members of the Financial Stability and Development system, Borensztein and Queijo Von Heideken (2016) report that ERPT is modest and has declined over time mainly due to pursuing a floating exchange rate system and increased credibility of monetary policy. However, currency depreciation continues to be a major factor of inflation in some of the countries.

Dilla, Achsani and Anggraeni (2017) examine the effect of inflation targeting on ERPT for nineteen high-income and middle-income countries. Among high-income countries, except for Norway, the other 7 countries experience decline in ERPT in the short run and long run after the adoption of inflation targeting. Among middle-income countries, 7 countries record decrease in ERPT whereas 4 countries experience increase in ERPT in the short run and long run after the adoption of inflation targeting.

Using the SVAR model and a sample of forty-seven countries, Ha, Stocker and Yilmazkuday (2019) find that countries with floating exchange rates and credible inflation targets are likely to have smaller pass-through ratios, that independence of central banks can ease the implementation of inflation stabilization, and that country characteristics, different global and domestic shocks tend to affect the pass-through ratios significantly.

Examining ERPT for eleven selected Latin American countries, Aguirre and González Padilla (2019) show that ERPT for Argentina declined from 0.59 during 1970-2016 to 0.15 during 2000-2016 and that ERPT for the whole sample also declined from 0.96 during 1970-2016 to 0.1 during 2000-2016 in the long run.

\section{The Model}

In the IS function, aggregate spending is a function of real income, government taxes, government spending, the real interest rate and the real exchange rate. In the LM function, real money demand is determined by the nominal interest rate, real income and the nominal exchange rate. In the aggregate supply function, the price level is affected by the expected price level, the output gap, the nominal exchange rate, and the energy cost. The extended IS-LM-AS model (Romer, 2006) can be written as:

$$
\begin{gathered}
Y=W\left[Y, T, G, R-\pi^{e}, X\left(P^{*} / P\right)\right] \\
M / P=Z(R, Y, X) \\
P=S\left(P^{e}, Y-Y^{*}, X, E\right)
\end{gathered}
$$

where

$\mathrm{Y}=$ real GDP in Argentina,

$\mathrm{T}=$ government taxes, 
$\mathrm{G}=$ government spending,

$\mathrm{R}=$ the nominal interest rate,

$\pi^{\mathrm{e}}=$ the expected inflation rate,

$\mathrm{X}=$ the nominal exchange rate measured as units of the Argentine peso per U.S. dollar,

$\mathrm{P}^{*}=$ the price level in the U.S.,

$\mathrm{P}=$ the price level in Argentina,

$\mathrm{M}=$ the money supply,

$\mathrm{P}^{\mathrm{e}}=$ the expected price level in Argentina,

$\mathrm{Y}^{*}=$ potential real GDP, and

$\mathrm{E}=$ the energy cost.

Suppose that $\mathrm{Y}^{*}$ does not change in the short term. Solving for the three endogenous variables, we obtain $\bar{P}$ as:

$$
\bar{P}=\bar{P}\left(X, M, G-T, E, P^{*}, P^{e}\right)
$$

The partial derivative of the equilibrium $\mathrm{P}$ with respect to the nominal exchange rate can be expressed as:

$$
\begin{gathered}
\partial \bar{P} / \partial X=\left[-Z_{R} S_{X}\left(1-W_{Y}\right)-W_{X} Z_{R} S_{Y}-W_{R} Z_{Y} S_{X}+W_{R} Z_{X} S_{Y}\right] /|J|>0 \text { if } Z_{X}<0 \\
<\text { or }>0 \text { if } Z_{X}>0 .
\end{gathered}
$$

where $|J|$ is the Jacobian matrix with a positive sign. The sign in equation (5) is unclear as the sign of the first three terms is positive whereas the sign of the last term depends on the sign of $Z_{X}$. The exchange rate may affect real money demand through the substitution effect and the wealth effect. If $Z_{X}<0$, the sign in equation (5) would be positive. If $Z_{X}>0$, the sign in equation (5) would be ambiguous (Arango and Nadiri, 1981).

\section{Empirical Results}

The data were taken from the International Financial Statistics, the St. Louis Federal Reserve Bank, and the World Economic Outlook. The CPI in Argentina is used as the dependent variable. The exchange rate is measured as units of the Argentine peso per U.S. dollar. An increase means depreciation of the Argentine peso. The money supply is represented by M2 money. Fiscal policy is represented by structural fiscal deficit or surplus as a percent of potential GDP. The energy cost is represented by the average crude oil price per barrel. The U.S. price level is represented by the export price index. The lagged CPI is used to represent the expected price level. The sample ranges from 1998 to 2019. Annual data for M2 before 1998 is not available.

The ADF test indicates that each time series variable has a unit root in level and is stationary in difference at the 5\% level. The ADF test on the residual shows that the test statistic is less 
than critical value at the $5 \%$ level, suggesting that these time series variables have a long-term stable relationship.

Figure 1 shows that the Argentine peso depreciated significantly in recent years. Figure 2 indicates that the CPI and the exchange rate seemed to be highly correlated during the 1998-2019. Depreciation of the Argentine peso led to a rise in the consumer price index. Figure 3 reveals that more M2 money supply caused the consumer price to rise.

\section{EXCHANGE_RATE}

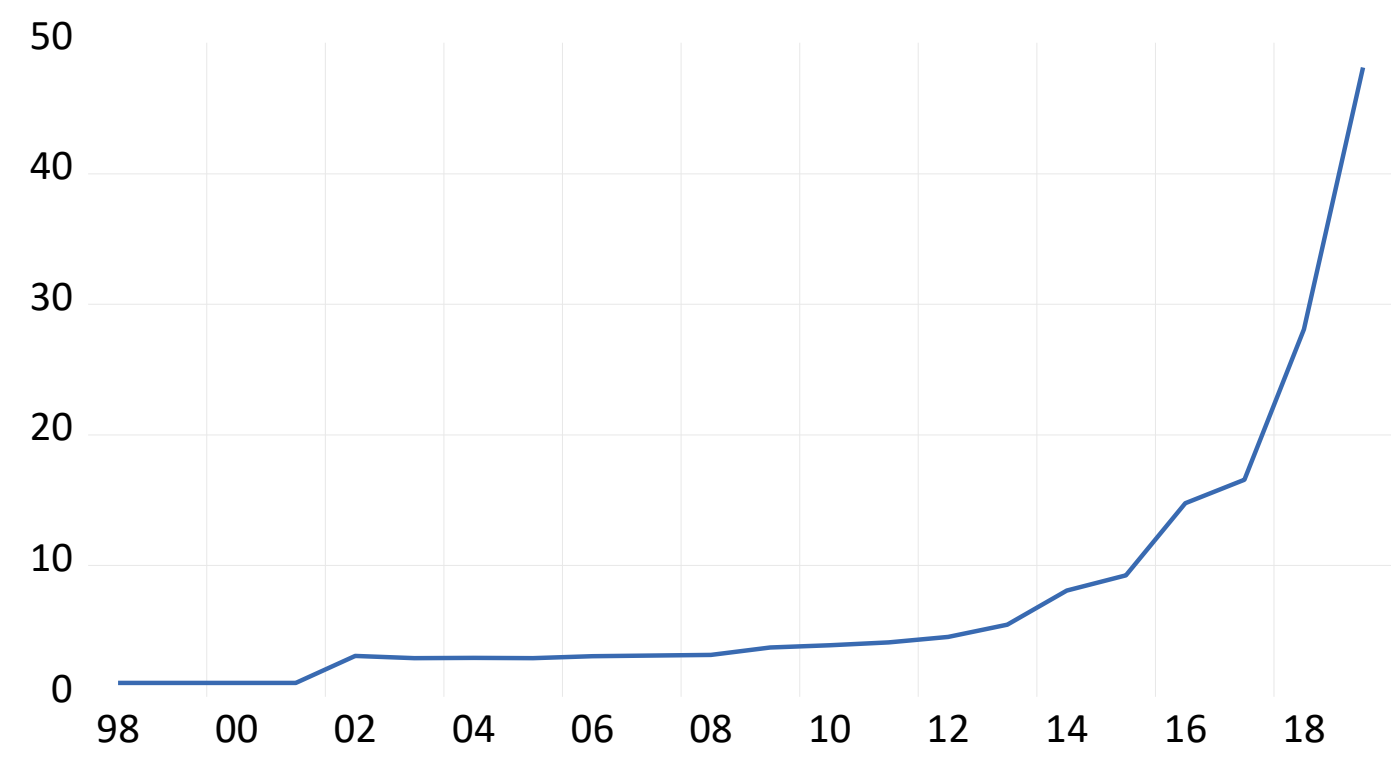

Figure 1. The Exchange rate between the Argentine Peso and the U.S. Dollar over Time

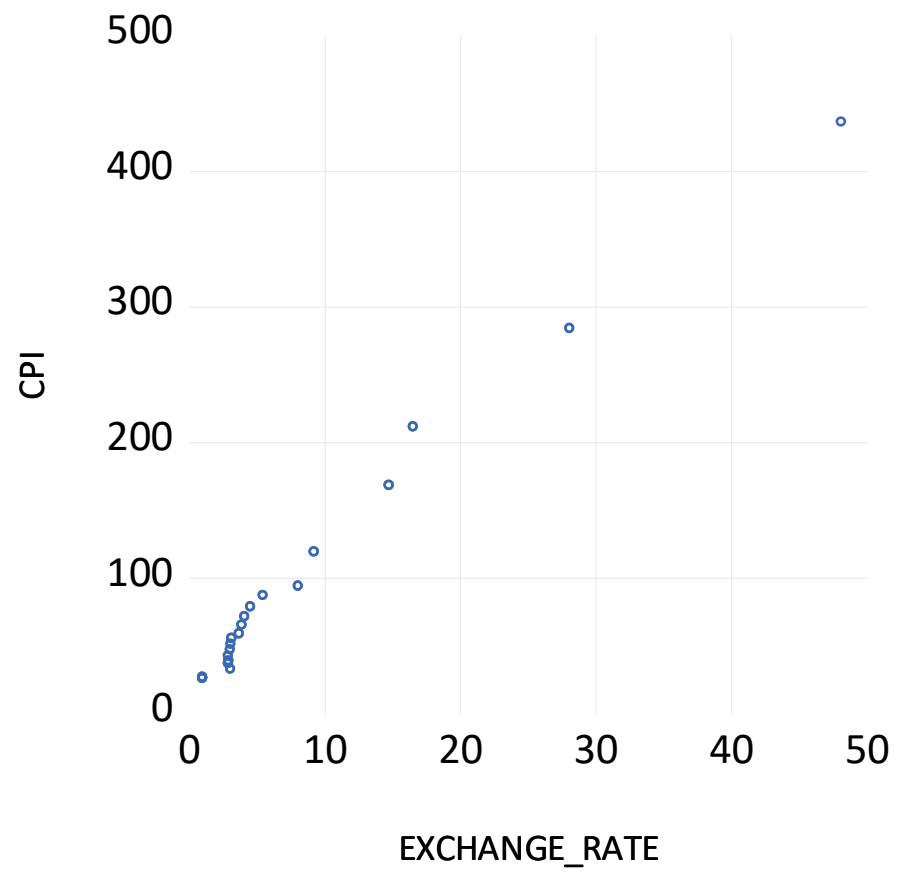

Figure 2. Scatter Diagram between the Consumer Price Index and the Exchange Rate 


\section{0}

400

300
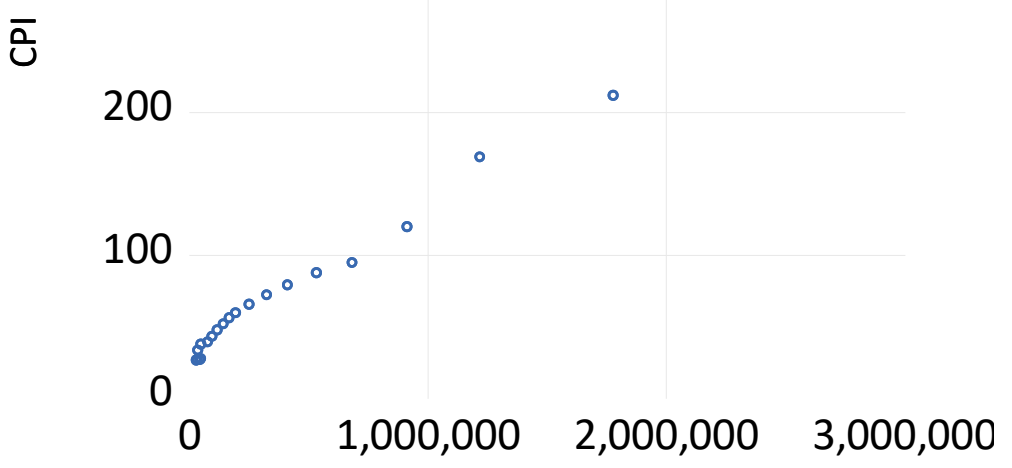

M2

Figure 3. Scatter Diagram between the Consumer Price Index and M2 Money Supply

Table 1 presents the estimated regression and related statistics. Except for structural fiscal deficit as a percent of potential GDP due to negative values in some years, other variables are measured in a log scale in order to reduce the degree of multicollinearity. The GARCH model is used to detect and correct for autoregressive conditional heteroskedasticity. Approximately 99.77\% of the change in the consumer price index (CPI) can be explained by the five right-hand side variables. Except for the coefficient of the oil price, the coefficients of other right-hand side variables are significant at the $1 \%$ or $5 \%$ level. The CPI has a positive relationship with the exchange rate, M2 money, structural fiscal deficit as a percent of potential GDP, the U.S. price, and the expected CPI.

If the ARS/USD exchange rate rises $1 \%$ or if the Argentine peso depreciates $1 \%$, the CPI would increase by $0.2518 \%$. Partial ERPT found in this study may be due to long-term contracts, rigid prices, absorption of higher prices by the parties concerned, net international capital outflows, etc. A 1 percent increase in M2 money would result in a $0.0101 \%$ rise in the consumer price. If government structural fiscal deficit as a percent of potential GDP rises by 1 percentage point, the log of the consumer price would decrease by 0.0086 , suggesting that fiscal expansion tends to raise the price level. If the U.S. price rises $1 \%$, Argentina's CPI would increase by $0.0187 \%$. If the expected CPI rises $1 \%$, the CPI would rise by $0.7195 \%$ These empirical results indicate that partial ERPT is confirmed and that the impact of other relevant variables cannot be overlooked.

In comparison, the degree of ERPT found in this paper is lower than 0.91 for emerging countries in the long run (Goldfajn and Werlang, 2000), 0.79 - 1.09 during high inflation periods in the long run (Choudhri and Hakura, 2006), 0.39 in the long run (Ca'Zorzi, Hahn 
and Sánchez, 2007), and 0.59 during 1970-2016 (Aguirre and González Padilla, 2019), close to 0.203 based on the fixed effect (Akofio-Sowah, 2009), and higher than 0.15 during 2000-2016 (Aguirre and González Padilla, 2019).

Table 1. Estimated Regression for the $\log (\mathrm{CPI})$ in Argentina

\begin{tabular}{|l|l|}
\hline Variable & Coefficient (Probability) \\
\hline Intercept & $0.7704(0.0000)$ \\
\hline Log(ARS/USD exchange rate) & $0.2518(0.0000)$ \\
\hline Log(M2 money) & $0.0101(0.0000)$ \\
\hline Structural fiscal deficit/potential GDP ratio & $0.0086(0.0000)$ \\
\hline Log(crude oil price) & $-0.0215(0.1142)$ \\
\hline Log(U.S. price level) & $0.0187(0.0366)$ \\
\hline Log(Expected CPI) & $0.7195(0.0000)$ \\
\hline R-squared & 0.9977 \\
\hline Adjusted R-squared & 0.9968 \\
\hline Sample period & $1998-2019$ \\
\hline Number of observations & 22 \\
\hline Mean absolute percent error & $3.0523 \%$ \\
\hline
\end{tabular}

Note: The ARS/USD exchange rate is measured as units of the Argentine peso per U.S. dollar. An increase means depreciation of the Argentine peso

\section{Summary and Conclusions}

This study has investigated the effect of ERPT on the consumer price in Argentina. Other relevant variables are also considered. A reduced-form equation based on an extended IS-LM-AS model is used in empirical work. The results show that a $1 \%$ increase in the ARS/USD exchange rate would lead to an increase in the consumer price by $0.2518 \%$, suggesting that partial ERPT to the consumer price is confirmed. Furthermore, a higher ratio of government structural fiscal deficit to potential GDP, more money supply, a higher U.S. price level, a higher crude oil price, and a higher expected consumer price in Argentina would raise the consumer price level in Argentina.

There are several policy implications. Recent trends of substantial depreciation of the Argentine peso tend to increase global competitiveness and stimulate net exports but raise domestic prices. The positive significant coefficient of government structural fiscal deficit as a percent of potential GDP may imply that authorities need to pursue fiscal prudence to maintain sustainability in the long run. Recent increase in world crude oil prices tends to cause domestic prices to rise. Authorities may need to contain the expected inflation or price level as its impact on the domestic consumer price is relatively large.

\section{References}

Aguirre, H. A., \& González Padilla, H. G. (2019). Exchange Rate Pass-Through, Monetary Policy and Real Shocks: An Empirical Evaluation. Economic Research Working Papers, No. 
85.

Akofio-Sowah, N. A. (2009). Is There a Link between Exchange Rate Pass-Through and the Monetary Regime? Evidence from Sub-Saharan Africa and Latin America. International Advances in Economic Research, 15, 296-309. https://doi.org/10.1007/s11294-009-9209-8

Arango, S., \& Nadiri, M. I. (1981). Demand for Money in Open Economies. Journal of Monetary Economics, 7, 69-83. https://doi.org/10.1016/0304-3932(81)90052-0

BBC. (2018). Argentina Asks IMF to Release \$50bn Loan as Crisis Worsens. BBC. 30 August 2018. Archived from the original on 24 November 2018.

Barhoumi, K. (2006). Differences in Long Run Exchange Rate Pass-Through into Import Prices in Developing Countries: An Empirical Investigation. Economic Modelling, 23, 926-951. https://doi.org/10.1016/j.econmod.2006.04.006

Borensztein, E., \& Queijo Von Heideken, V. (2016). Exchange Rate Pass-Through in South America: An overview. https://doi.org/10.18235/0000499

Campa, J., \& Goldberg, L. (2005). Exchange Rate Pass Through into Import Prices. The Review of Economics and Statistics, 87, 679-690.

https://doi.org/10.1162/003465305775098189

Castillo-Ponce, R. A., \& Lai, K. S. (2020). On Argentina's Currency Crisis of 2018. Lecturas de Economía, 92, 223-233. https://doi.org/10.17533/udea.le.n92a08

Ca'Zorzi, M., Hahn, E., \& Sánchez, M. (2007). Exchange Rate Pass-Through in Emerging Markets. Working paper.

Cheikh, N. B., \& Louhichi, W. (2016). Revisiting the Role of Inflation Environment in Exchange Rate Pass-Through: A Panel Threshold Approach. Economic Modelling, 52(Part A), 233-238. https://doi.org/10.1016/j.econmod.2014.11.004

Coulibaly, D., \& Kempf, H. (2010). Does Inflation Targeting Decrease Exchange Rate Pass-Through in Emerging Countries? Working Paper. https://doi.org/10.2139/ssrn.1706025

Choudhri, E. U., \& Hakura, D. S. (2006). Exchange Rate Pass-Through to Domestic Prices: Does the Inflationary Environment Matter? Journal of international Money and Finance, 25, 614-639. https://doi.org/10.1016/j.jimonfin.2005.11.009

Dilla, S., Achsani, N. A., \& Anggraeni, L. (2017). Do Inflation Targeting Really Reduced Exchange Rate Pass-Through? International Journal of Economics and Financial Issues, 7, 444-452.

Goldfajn, I., \& Werlang, S. (2000). The Pass-Through from Depreciation to Inflation: A Panel Study. Banco Central do Brasil Working Paper 5. Brasilia, Brazil: Banco Central do Brasil. https://doi.org/10.2139/ssrn.224277

Ha, J., Stocker, M., \& Yilmazkuday, H. (2019). Inflation and Exchange Rate Pass-Through. Public Research Working Paper, No. 8780, The World Bank. 
https://doi.org/10.1596/1813-9450-8780

Mihaljek, D., \& Klau, M. (2008). Exchange Rate Pass-Through in Emerging Market Economies: What Has Changed and Why? BIS papers, 35, 103-130.

Romer, D. (2006). Advanced macroeconomics (3rd ed.). Boston: McGraw-Hill/Irwin.

\section{Copyright Disclaimer}

Copyright for this article is retained by the author(s), with first publication rights granted to the journal.

This is an open-access article distributed under the terms and conditions of the Creative Commons Attribution license (http://creativecommons.org/licenses/by/4.0/). 